\title{
Pragmatism keeps Berlin centre alive
}

Berlin. A plan to keep in being a group of research institutes at Adlashof, a suburb of southeast Berlin, is likely to be agreed next month. This development should make good the most conspicuous flaw so far to come to light in the otherwise successful programme for reshaping the pattern of research in the East masterminded by Germany's science council (Wissenschaftsrat) during 1991.

Before reunification, the 50 -hectare Adlashof site was occupied by nine chemistry and physics institutes of the former Academy of Sciences and a large centre for making western-type instruments. The original

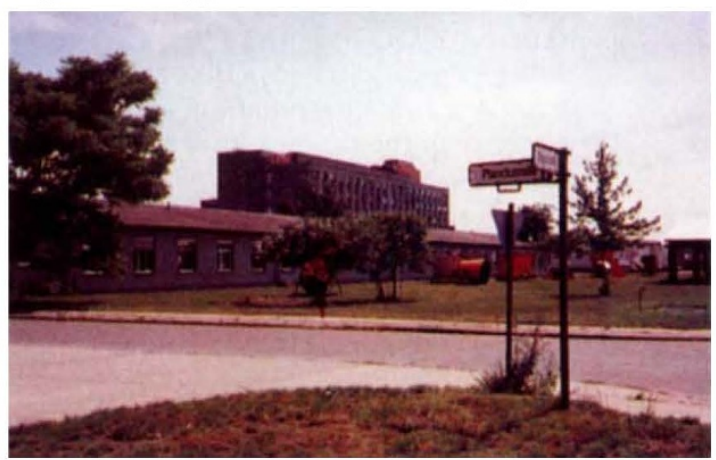

Reprieved: the Chemistry Centre in east Berlin.

workforce of 5,500 workers has already fallen to 3,800 and will fall further, by a third, when special 'rescue funds' run out at the end of the year.

The provision of the reunification treaty that academy institutes should either be closed down or given another status meant that much of the research at Adlashof was taken over piecemeal by the four main pillars of German research - the Max Planck Society, the Fraunhofer Society (for applied research), the national research centres and 'Blue List' institutes (which are equally funded by the federal and Länder governments). Industry also showed some interest, while several groups were given grants to set up small businesses.

But somehow the nucleus of chemical research at Adlashof, although favourably evaluated, fell through the net. Although four institutes (for inorganic polymer chemistry, heterogeneous catalysis, macromolecular chemistry and organic synthesis) were graded as excellent, the Wissenschaftsrat's 1991 proposals for their continuing support have fallen apart.

The Wissenschaftsrat recommended that staff numbers should fall from 1,700 to 325 . At this stage, it was idealistically aiming to reintegrate research into the universities from which it had been all but banished 20 years earlier. It also recommended that, over a period of seven years, the institutes should either form an outpost of the Humboldt University in Berlin or separately move to other universities in the east.

Events have shown that the universities had enough to handle with their own restructuring and staff reductions (see Nature 362,$775 ; 1993$ ), while the idea of moving a whole institute hundreds of kilometres was clearly impractical.

But financial quarrels proved decisive. If the centre were a university institute, the Land (state) of Berlin would be responsible for the whole cost, but as an independent research institute, the federal government would have to share the expense. Nobody in Berlin was convinced that an expensive chemical research centre in a city without a chemical industry could be a priority. "The Land refused to take it on", says Jochen Stoer of Berlin's ministry of science and art. So the staff at the chemistry centre are being paid from a special fund (called WIP) intended to support individual scientists moving from institutes to universities, but that fund will end in December.

Various contingency plans have been cooked up and rejected. Then, last February, the Wissenschaftsrat was asked to try again. It asked for more staff cuts (down to 220) and suggested that the centre should become a 'Blue List' institute, meaning that the Land and federal governments would split the costs equally. But the Wissenschaftsrat said it would not make that proposal formally until the two governments had agreed to share the costs.

This was a wise precaution. Had the suggestion to fund a Blue List institute been made at the outset, it would certainly have been accepted. But now the federal government believes that too many such institutes have already been founded in the new Länder (see Nature 363, 482; 1993). Finance minister Theo Waigel has enunciated the omnibus principle: no new Blue List institute unless an old one is closed.

Months of carrot-and-stick negotiation may nevertheless now bear fruit. The centre has won support from the previously sceptical Berlin science minister, Manfred Erhardt, who seems this month to have reached an understanding with federal research minister Paul Krüger (himself an east German). And the federal research ministry is prepared to pay half the cost of the centre for ten years provided that it is not formally established as an institute of any kind.

Berlin will match federal support alone, without calling on the other five eastern Länder to which Blue List status would have entitled it. But Berlin will administer the centre just as it does its eight Blue List institutes. The federal and Berlin governments are believed ready to accept this pragmatic solution after it is formally proposed by the Wissenschaftsrat on 9 July.

Researchers at the Chemistry Centre welcome the new concept of an institute in fact if not in name. "Ten years is a very long time for us to prove our worth", says department head Manfred Meisel. With nearly 600 publications and 27 patent applications last year, they have reason to be confident.

Alison Abbott

\section{NIH appointment due}

Washington. The Clinton administration is believed to be considering two very different candidates to direct the National Institutes of Health (NIH), the United States' main biomedical research institution.

Dr Judith Rodin, a psychologist and provost of Yale University, and Dr Harold Varmus, a Nobel Prize winning cancer researcher from the University of California at San Francisco, are being considered to replace Bernadine Healy as director of the NIH. Healy, who was appointed to the post by former president George Bush, is to vacate the position by 1 July.

While both Rodin and Varmus come highly recommended by a search committee of scientists, they would each be likely to emphasize different roles for the government-funded $\mathrm{NIH}$, whose budget this year will exceed $\$ 10$ billion. Rodin, 48 , is an experienced administrator and a behavioural scientist known for her research on aging and eating disorders. She would be expected to bring a social slant to the agency's approach towards research, emphasizing, for example, disease prevention and women's health issues.

For his part, Varmus has heavy ties to the biomedical research community. Although trained as a doctor, Varmus, 53, has worked primarily in molecular biology, winning the 1989 Nobel Prize for his research on the genes that cause cancer. He has no administrative background, but has taken an active interest in science policy and has testified several times to Congress on biomedical research. Insiders say that Varmus's nomination has been recommended to President Clinton by Health and Human Services Secretary Donna Shalala, who oversees the NIH.

The selection process has been less rocky so far than the last time an NIH director was chosen. In 1991, Healy, a cardiologist, was chosen after several candidates turned down the job because, under the Bush administration, they would have had to publicly oppose abortion and fetal research.

"We're not seeing any ideological litmus testing going on in this process," said Lynn Morrison, director of public policy for the American Federation for Clinical Research, a New Jersey-based lobby group. "The administration is trying to find the right person to run the NIH, not the right person for its particular political stance." Susan Greene 